\title{
In vivo Anti-inflammatory Activity of Aqueous Extract of Carthamus caeruleus L Rhizome Against Carrageenan-Induced Inflammation in Mice
}

\author{
Amari Nesrine Ouda ${ }^{1}$, Missoun Fatiha ${ }^{1,{ }^{*}}$, Mansour Sadia ${ }^{1}$, Sekkal Fatima Zohra ${ }^{2}$ and \\ Djebli Noureddine ${ }^{1}$
}

${ }^{1}$ Laboratory of Pharmacognosy and Api-Phytotherapy, University of Mostaganem (UMAB), Mostaganem 27000, Algeria; ${ }^{2}$ Laboratory of Biodiversity and Conservation of Water and Soil ,University of Mostaganem (UMAB), Mostaganem 27000, Algeria.

Received: July 27, 2020; Revised: October 28, 2020; Accepted: November 12, 2020

\begin{abstract}
Carthamus caeruleus $L$ belongs to the family Asteraceae and is reported to have anti-inflammatory, anti-burns and wound healing properties. The aim of the present study was to evaluate the anti-inflammatory activity of aqueous extract of Carthamus caeruleus $L$ rhizome in mice. Carrageenan was used to induce inflammation in mice; the percentage inhibition of edema (\% INH), the percentage increase in paw edema volume (\% AUG) and histological study were used to evaluate the anti-inflammatory activity.

Phytochemical investigations indicate the presence of Carotenoids, flavonoids, terpenoids and steroids, tannins, saponins, coumarins, quinons, mucilage, proteins and glycosides and a very low quantity of phenolic compounds $(13.08 \pm 0.22 \mathrm{mg}$ GAE/g extract) and flavonoids (5.02 $\pm 0.55 \mathrm{mg} \mathrm{QE} / \mathrm{g}$ extract) in the rhizome of Carthamus caeruleus $L$. In acute toxicity test, the oral doses of plant extract administered to mice were not toxic. Our findings show that the treatment with aqueous extract of Carthamus caeruleus $L$ presents a significant inhibitory activity in carrageenan-induced paw inflammation in group A (dose $150 \mathrm{mg} / \mathrm{kg}$ ) and B (dose $300 \mathrm{mg} / \mathrm{kg}$ ) compared with the standard drug Diclofenac during the whole period of experimentation; these results were confirmed by the histological study in the paws of mice. Carthamus caeruleus $L$ appears to be a promising plant for further preclinical and clinical trials in inflammation.
\end{abstract}

Keywords: Carthamus caeruleus L, Inflammation, Carrageenan, Rhizome, Paw edema, Phytoconstituents.

\section{Introduction}

Inflammation is a process of immune defense of the organism in response to an aggression of exogenous origin (burn, infection, allergy, trauma) or endogenous (cancer cells or autoimmune pathologies) .The clinical symptoms of those inflammation processes are: redness, heat, swelling and pain, moreover, the function of the inflamed organ can be impaired. At the tissue level, the inflammatory response is characterized by an increase in vascular permeability, an increase in the denaturation of proteins and the alteration of cell membranes. (Winter, 1967; Roitt et al., 2001). Chronic inflammation is the main cause of continuing disorders, such as autoimmune diseases, allergies, metabolic syndrome, cardiovascular dysfunctions and Cancer and imposing an enormous economic burden on individuals and therefore on society (Sarkar, 2020; Bagad et al., 2013; Sreedam et al., 2012).

Various effective anti-inflammatory drugs can reduce pain and inflammation by the inhibition of the metabolism of arachidonic acid by the isoform of the enzyme cyclooxygenase (COX-1 and/or COX-2), thereby reducing the production of prostaglandin (Payan et al., 1995) . Unfortunately, there are many side effects associated with the administration of nonsteroidal antiinflammatory drugs like headache, gastric ulcer, damage of liver function (Oguntibeju et al ., 2018) .

Over the past decade, phytotherapy has become more important, making an impact on both health and international trade. Return to natural products is essential as it would be less toxic and equally effective (Missoun et al., 2017). Algeria has a diverse climate and a large geographical location, making it a treasure trove of medicinal plants; furthermore, the trade of plants is very easy and cheap. In addition, many people are interested in having more autonomy over their medical care in Algeria.

For this reason, we have chosen for our study Carthamus caeruleus L .In traditional medicine, this plant is used to prepare ointment by boiling the rhizomes in water until becoming beige cream and using it against burns, inflammation and skin rejuvenation in a deep burn. GC / MS analysis made by Dahmani, et al (2018) indicated the presence of very interesting phytochemicals in the rhizomes of Carthamus caeruleus $L$ collected from Tizi Ouzou north of Algeria, as an example: $\mathrm{n}$ -

\footnotetext{
* Corresponding author e-mail: fatiha.missoun@yahoo.fr.

** Abbreviation:NFאB = nuclear factor, iNOS: inducible nitric oxide synthase, NO: nitric oxide, ICAM: intercellular adhesion molecule,

VCAM: vascular cell adhesion molecule, PECAM: platelet endothelial cell adhesion molecule, IL: interleukin, TNF: tumor necrosis

factor, MCP: monocyte chemoattractant protein.
} 
hexadecanoic acid (palmitic acid), mono (2-ethylhexyl) phthalate (MEHP); this molecule is known for its antiinflammatory , antifungal, antidiabetic, antioxidant, antitumor, and antimicrobial effects. The enzyme kinetics study proved that n-hexadecanoic acid inhibits phospholipase $\mathrm{A}(2)$ in a competitive manner (Vasudevan et al., 2012).

This study focuses on the anti-inflammatory effect of Carthamus caeruleus L rhizome collected from Mostaganem region on mice. The inflammation process was induced by lipopolysaccharide called carrageenan and treated thereafter by Carthamus caeruleus L rhizome aqueous extract.

\section{Materials and methods}

\subsection{Plant material}

Carthamus caeruleus $L$. rhizomes were collected in August 2018 from Sidi lakhder region, Mostaganem city, west of Algeria. The samples were taken randomly and transported in black plastic bags to the laboratory. Samples were identified by Dr. Sekkal FZ, and a voucher specimen (C.C .Sidi Lakhder/2018) of the plant was kept at the Herbarium of Laboratory of Pharmacognosy \& Api Phytotherapy, University of Mostaganem, Algeria, for future reference. After washing and drying, the samples were crushed and sieved to obtain a fine powder which was used for the preparation of the extracts. It has been preserved in a hermetic bottle protected from light.

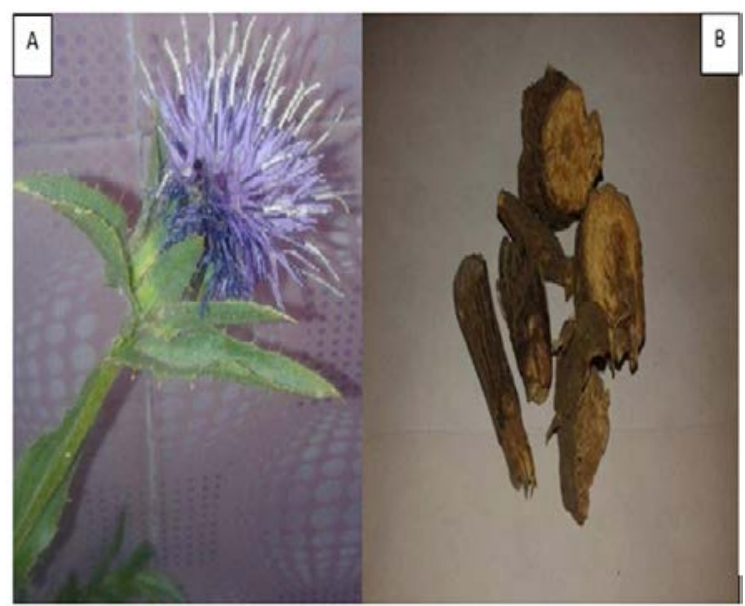

Figure 1 . Photography of Carthamus caeruleus L .A : Stem and flower, B : Rhizome

\subsection{Preliminary phytochemical screening}

\subsubsection{Qualitative Analysis}

Colorimetric methods were carried out on the methanolic and aqueous extract and on the powdered specimens using standard procedures to identify Alkaloids, Flavonoids, Quinones, Tannins, Saponins, Coumarins, Carotenoids, Triterpenoids, Sterols, Proteins, Glycosides, Combined anthraquinones, Mucilages as described by Harborne (1998), Trease et al (2009), Sofowara (1993) and Ayoola et al (2008).

\subsubsection{Quantitative Analysis : Total phenolic and flavonoid content}

The total phenolic content was determined by the Folin reagent method Ciocalteu (FCR) (Mruthunjaya et al .,
2016). One milliliter $(1 \mathrm{ml})$ of the plant methanol extract was mixed with FCR (diluted 10 times). After standing for 5 min at $22{ }^{\circ} \mathrm{C}$, a volume of $750 \mathrm{ml} \mathrm{NaCO}$ was added to the mixture. The absorbance was measured at $725 \mathrm{~nm}$ by spectrophotometer (Shimadzu UV mini1240). The content of TPCs of each extract was estimated by comparison with the standard curve generated from gallic acid. The results were expressed in gallic acid equivalents (mg GAE / g extract).

The flavonoid content is determined using quercetin as a reference compound. One milliliter $(1 \mathrm{ml})$ of plant extract in methanol was mixed with $1 \mathrm{ml}$ chloride aluminum. The absorbance was read at $415 \mathrm{~nm}$. The flavonoid content was expressed in mg quercetin / $\mathrm{g}$ extract. The amount of flavonoids in Carthamus caeruleus $L$ extracts in quercetin equivalents $(\mathrm{QE})$ was calculated by the following formula:

$$
F=\left(A \cdot W_{0}\right) /\left(A_{0} \cdot W\right)
$$

Where $\mathrm{F}=$ flavonoid content was expressed as milligrams of QE/milligrams of plant extracts.

$A=$ absorbtion of plant extracts solution, $A_{0}=$ absorbtion of standard quercetin solution,

$W_{0}=$ weight of standard quercetin solution in $\mathrm{mg}, \mathrm{W}=$ weight of the plant extract in $\mathrm{mg}$.

\subsection{Experimental design}

\subsubsection{Plant Extract Preparation for in vivo anti- inflammatory activity}

$1000 \mathrm{~mL}$ of distilled water was added to $100 \mathrm{~g}$ of rhizome dry powder, let boiled for $60 \mathrm{~min}$. The dark yellow extract was filtered by using Whatman filter paper. The filtrate was then lyophilized conserved until use for anti-inflammatory activity in mice. Yield obtained from rhizomes extraction was $15 \%$.

\subsubsection{Acute toxicity study}

Acute toxicity study was assessed in mice by using an acute oral toxic class method of Organization of Economic Co-operation and Development (OECD), guidelines (OECD/OCDE, 2000 ) .This test consists in administering gradual doses ( $300 \mathrm{mg}, 500 \mathrm{mg}, 1000 \mathrm{mg} / \mathrm{kg} \mathrm{BW}$ ) to the animals and observed for any manifestation of toxicity, increase in locomotor activity, salivation, convulsion, coma and death. These observations are made regularly up to 24 hours.

\subsubsection{In vivo anti-inflammatory activity}

Twenty eight healthy adult female mice NMRI weighing $33 \pm 5 \mathrm{~g}$ were obtained from Algerian Pasteur Institute. Animals were kept in polyacrylic cages and maintained under standard housing conditions (room temperature at $25 \pm 5^{\circ} \mathrm{C}$ with $12: 12$ light: dark cycles) and water ad libitum. Food was provided by dry pellets. Animals were randomly divided into four groups of seven mice each. Experimental work was carried out at UMAB in accordance with the Algerian Legislation (Law Number 12-235/2012) inherent to the protection of animals designed to experimental and other scientific purposes as well as with the guidelines of the Algerian Association of Experimental Animal Sciences (AASEA).

All animals were fasted $18 \mathrm{~h}$ before testing. The duration of experimentation was 6 hours, with each group receiving the experimental solutions orally one hour before the injection of carrageenan as follows: 
Control Carrageenan group C $(\mathrm{n}=7)$ : Physiological water $\mathrm{NaCl}(0,9 \%)$.

Standard group St $(\mathrm{n}=7)$ : Was given an antiinflammatory medicine (Diclofénac dissolved in $\mathrm{NaCl}$ $0,9 \%$ with concentration of $10 \mathrm{ml} / \mathrm{kg}$ ).

Group A $(n=7)$ : Aqueous extract of Carthamus caeruleus L (150 mg/Kg de BW dissolved in $\mathrm{NaCl}$ 0,9\%).

Group B (n=7): Aqueous extract of Carthamus caeruleus $L$ (300mg/Kg de BW dissolved in $\mathrm{NaCl} \mathrm{0,9 \% ).}$

One hour after the administration of the treatments, each animal in all groups received, by sub-plantar injection in the right hind paw, $0.1 \mathrm{ml}$ of a $0.1 \%$ carrageenan a highmolecular-weight polysaccharide induced paw edema model (Alwashli et al., 2012; Bignotto et al., 2009) dissolved in $0.9 \% \mathrm{NaCl}$.

\subsubsection{Evaluation of anti-inflammatory activity}

a. The percentage increase in paw edema volume (\% $A U G)$

The diameter of the paw was measured, using a digital micrometer before and after induction of inflammation at intervals of one hour for six hours . The percentage increase in paw edema volume (\% AUG) was calculated for each group of mice. It is given by the following formula :

$$
\% \text { AUG }=(\text { Dn-D0) X } 100 / \text { D0 }
$$

Dn: Diameter of the leg the $n$ hour after the injection of the carrageenan.

D0: Diameter of the leg before the injection of the carrageenan.

b. Calculation of the percentage inhibition of edema (\% INH)

The percentage inhibition (\% INH) of the edema was calculated for each group of mice treated relative to the control. It is obtained by the following formula

$\%$ INH $=(\%$ AUG control - \% AUG treated $) * 100 / \%$ AUG control

$\%$ INH : the percentage inhibition of edema

$\%$ AUG : The percentage increase in paw edema volume

\subsection{Histopathological examination}

Two mice were randomly selected from each group for histopathological investigations. Tissue samples were taken 6 hours after the induction of inflammation, legs were fixed in $10 \%$ formalin, decalcified with a decalcifying solution $(980 \mathrm{ml}$ of distilled water $+20 \mathrm{ml}$ of nitric acid), for three hours, incorporated into paraffin and sectioned to obtain paraffin sections $4 \mu \mathrm{m}$ thick using a slide microtome. The tissue sections obtained were collected on glass slides, dewaxed in xylene, hydrated in descending series of ethyl alcohol, stained with hematoxylin and eosin (H\&E) stains, dehydrated in ascending series of ethyl alcohol, eliminated in two changes of xylene, assembled with DPX (Bancroft et al., 2008) then examined with optical microscope.

\subsection{Statistical analysis}

For numerical outcomes, one-way analysis of variance (ANOVA) with Tukey-Kramer Multiple Comparisons post tests were performed using GraphPad InStat Version 3 (GraphPad Software) and all graphs were made by utilizing Microsoft office 2007 software. The results were expressed as an average \pm SEM. The values of $p<0.05$; $p$
$<0.01$; p $<0.001$ were considered significant $(*)$, very significant $(* *)$ and highly significant $(* * *)$ respectively.

\section{Results}

\section{1. phytochemical screening}

In this study, the phytochemical screening of Carthamus caeruleus $L$ rhizomes extracts has shown that this herb contains : Flavonoids, carotenoids, terpenoids and steroids, tannins, saponins, combined anthraquinones, coumains, quinons, mucilage, proteins and glycosides, whereas the absence of alkaloids (table 1).

The Flavonoids and Total phenolic compound contents of Carthamus caeruleus $L$ are shown in table 2. The results are expressed in milligram equivalent (standard) per gram of dry powder extract (mg standard E/g DM), using the equation of the linear regression of the calibration curve plotted from the corresponding standard (Quercetin, Gallic acid, respectively). Results show very low quantity of phenolic compounds (13.08 $\pm 0.22 \mathrm{mg}$ GAE/g extract) and flavonoids (5.02 $\pm 0.55 \mathrm{mg} \mathrm{QE} / \mathrm{g}$ extract) in the rhizome part of Carthamus caeruleus $L$.

Table 1. The results of phytochemical screening of Carthamus caeruleus $L$

\begin{tabular}{lll}
\hline $\begin{array}{l}\text { Class of } \\
\text { compounds }\end{array}$ & Test name or reagent & $\begin{array}{l}\text { C. Caeruleus } \\
\text { extract rhizome }\end{array}$ \\
\hline Alkaloids & $\begin{array}{l}\text { Mayer and Dragendorff's } \\
\text { reagent }\end{array}$ & - \\
Flavonoids & Shinoda test & + \\
Quinones & NAOH + Extract & +++ \\
Tannins & Ferric chloride test & +++ \\
Saponins & Froth test & +++ \\
Coumarins & Fluorescence test & + \\
Carotenoids & Carr-Price reaction & ++ \\
Triterpenoids & Salkowski's test & +++ \\
Sterols & Libermann-Burchard test & +++ \\
Proteins & Trichloroacetic acid test & +++ \\
Glycosides & Legal test & +++ \\
Combined & Borntrager's test & +++ \\
anthraquinones & Extract + Alcohol & +++ \\
Mucilages & & + \\
\hline
\end{tabular}

-Absence, +Presence in low concentration, ++Presence,

+++ Presence in high concentration

Table 2. Flavonoids and Total phenolic compound contents of Carthamus caeruleus $L$

\begin{tabular}{lll}
\hline Samples & $\begin{array}{l}\text { Flavonoids } \\
\text { (mg Quercetin } \\
\text { equivalent/g of } \\
\text { extract) }\end{array}$ & $\begin{array}{l}\text { Total phenolic } \\
\text { compound } \\
\text { (mg Gallic acid } \\
\text { equivalent/g of extract) }\end{array}$ \\
\hline $\begin{array}{l}\text { Alcoholic } \\
\text { Extract }\end{array}$ & $5.02 \pm 0.55$ & $13.08 \pm 0.22$ \\
\hline
\end{tabular}

\subsection{In vivo anti-inflammatory activity}

Oral administration of the aqueous extract of rhizome of Carthamus caeruleus $L$ at doses of $(300 \mathrm{mg}, 500 \mathrm{mg}$, $1000 \mathrm{mg}$ ) / kg BW to mice did not induce any signs of acute toxicity during the $24 \mathrm{~h}$ of observation. 
The percentage increase in paw edema volume (\%AUG) that carrageenan administration significantly increased ( $\mathrm{p}<0.001)$ the paw edema in mice in the first hour of the experiment (figure 2) .The administration of the anti-inflammatory drug Diclofenac $(50 \mathrm{mg} / \mathrm{kg}$ ) in the second group (St) significantly decreased the paws edema from the second hour in mice up to the fifth hour of the experiment.

Treatment with the aqueous extract of the rhizome of Carthamus caeruleus L (150 mg / kg) induces a significant decrease in the volume of the mice's paws edema during the second, third, fifth and sixth hours of the experiment ( $\mathrm{P}$ $<0.01$ ). (Figure 2). Treatment with dose of $300 \mathrm{mg} / \mathrm{kg}$ induces a highly significant reduction over the 6 hours compared to Carrageenan control group.
On the other hand, the results of the percentage inhibition of edema (\% INH) indicate that after the first and second hour (Figure 3), the treatment with the oral administration of the aqueous extract of Carthamus caeruleus $L$ at the dose $300 \mathrm{mg} / \mathrm{kg}$ caused a highly significant inhibitory activity in carrageenan-induced paw inflammation compared to the group treated with the extract at a dose of $150 \mathrm{mg} / \mathrm{kg}$ BW and standard group (P $<0.001)$.

Our results show that the treatment with aqueous extract of Carthamus caeruleus $L$ presents an antiinflammatory activity in group A and B compared to the standard drug Diclofenac during the whole period of experimentation.

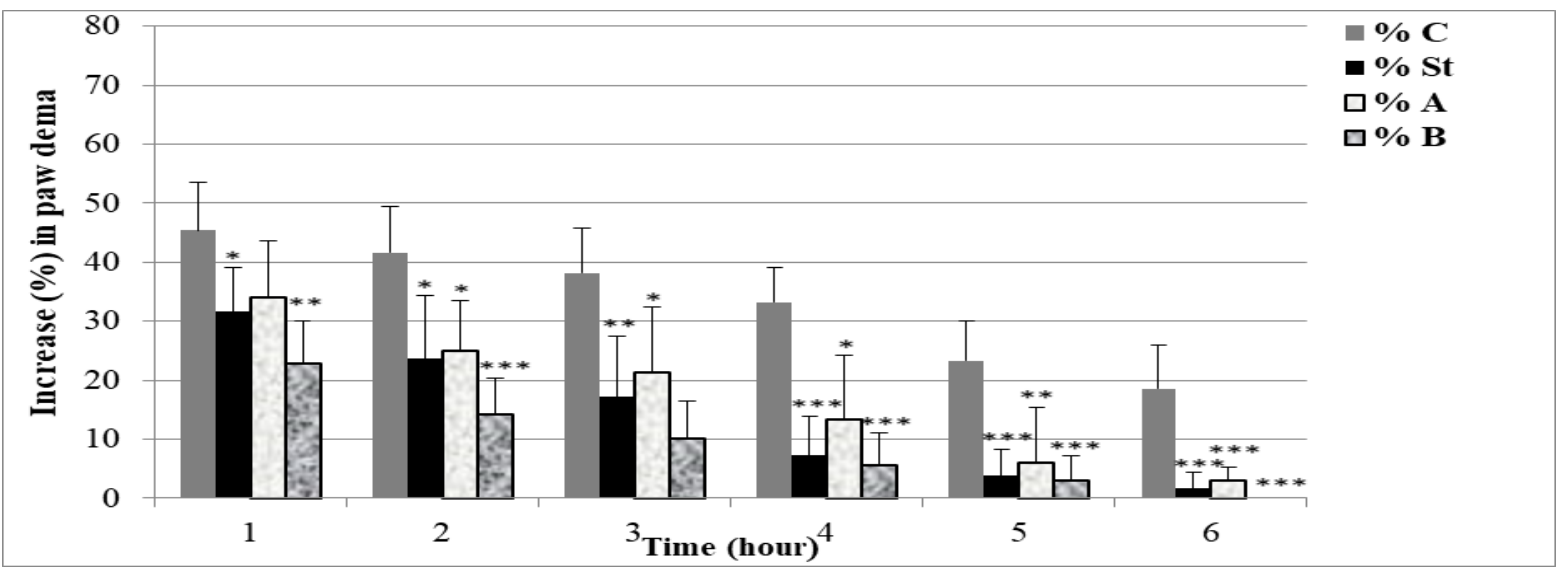

Figure 2. The percentage increase in paw edema volume (\%AUG). Mice were divided randomly into four groups: Control (C) Carrageenan group , Diclofenac (St) group (50mg/kg), C. Caeruleus (A) groups (150mg/kg) and C. Caeruleus (B) groups (300mg/kg). Results are expressed as the mean $\pm \mathrm{SD}\left(\mathrm{n}=7\right.$ animals per group). ${ }^{*} \mathrm{p}<0.05,{ }^{* *} \mathrm{p}<0.01,{ }^{* * *} \mathrm{p}<0.001$ were considered significant when compared with the Control carragenan group (C).

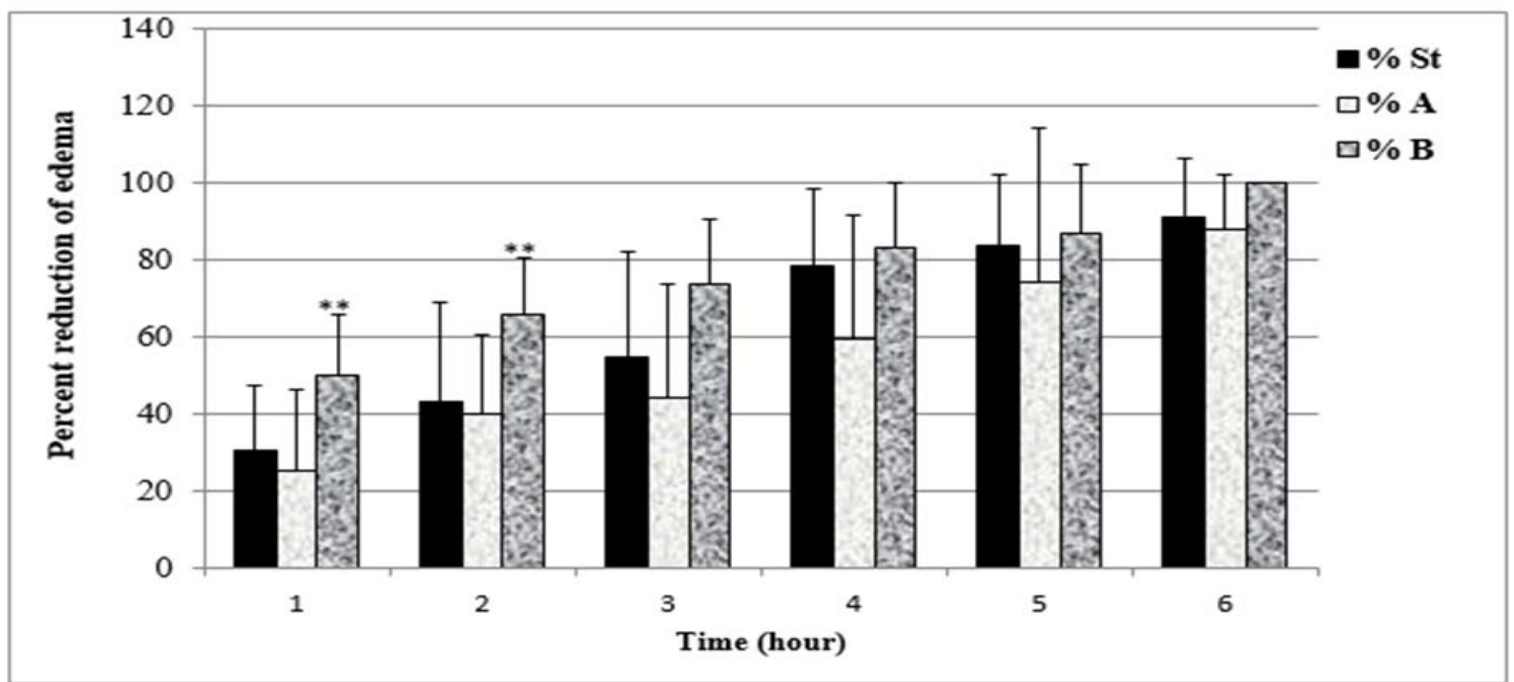

Figure 3 . Effect of Carthamus caeruleus on percentage inhibition of edema (\% INH). Mice were divided randomly into four groups : Control carrageenan group , Diclofenac (St) group (50mg/kg), C. Caeruleus (A) groups (150mg/kg) and C. Caeruleus (B) groups $\left(300 \mathrm{mg} / \mathrm{kg}\right.$ ). Results are expressed as the mean $\pm \mathrm{SD}$ ( $\mathrm{n}=7$ animals per group). ${ }^{*} \mathrm{p}<0.05,{ }^{* *} \mathrm{p}<0.01,{ }^{* * *} \mathrm{p}<0.001$ were considered significant when compared with the Standard group (St).

\subsection{Histological study}

The histological study in the paw tissues of control carrageenan mice showed severe acute inflammation with dense infiltration comprising of neutrophils and lymphocytes (chronic inflammatory cells). The epidermis showed sponge-like appearance. Necrosis, exudates ,polymorphic associated with edema were also noted (Figure 4) .In the group treated with Diclofenac, we noticed the disappearance of edema and tissue congestion, decrease in the intensity of the inflammatory infiltrate 
were observed compared to the carrageenan control. Treatment with the aqueous extract of the rhizome of Carthamus caeruleus $L$ in the doses of $150 \mathrm{mg} / \mathrm{kg}$ and $300 \mathrm{mg} / \mathrm{kg}$ reduce inflammatory response with few proliferation blood vessel and minimal number of inflammatory cells.
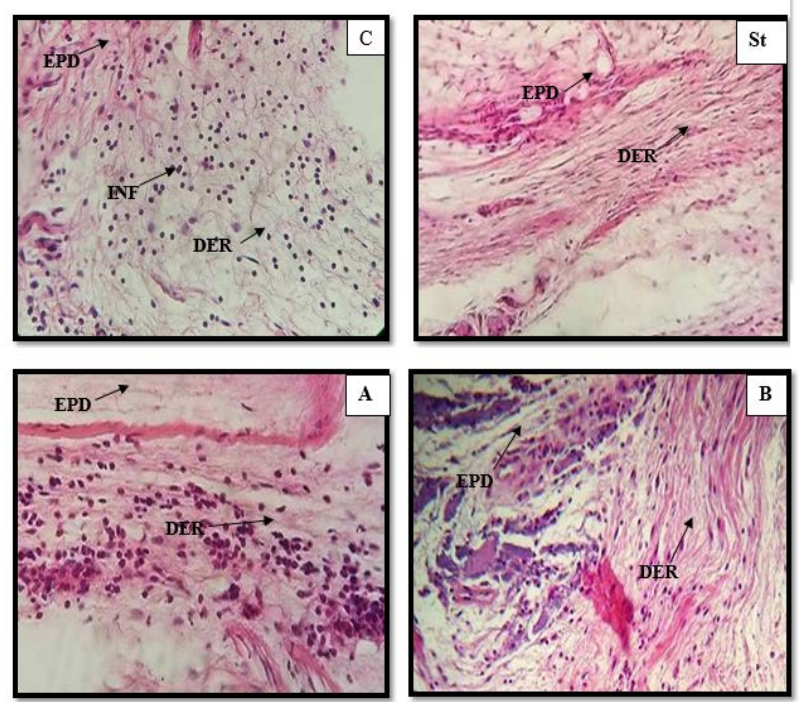

Figure 4. Photographs from the skin of mice paw tissue showing the protective effect of Carthamus caeruleus against carrageenan-induced inflammation. Control carrageenan (C), Diclofenac (St) group $(50 \mathrm{mg} / \mathrm{kg})$, C. Caeruleus (A) group (150mg/kg) and C. Caeruleus (B) group $(300 \mathrm{mg} / \mathrm{kg})$, EPD: epidermis, Der: dermis, INF $\rightarrow$ : lymphocytic infiltration. (X40)

\section{Discussion}

In this study, the potential anti-inflammatory effects of aqueous rhizome of Carthamus caeruleus $L$ collected from Mostaganem west of Algeria were investigated using female NMRI mice as animal models, carrageenan was used to induce paw edema model . The percentage inhibition of edema (\% INH ), the percentage increase in paw edema volume (\% AUG) and histological study were used to evaluate the anti-inflammatory activity of the test substance.

Our results of phytochemical screening are in the same order with the results of Dahmani et al (2018) and Benhamou et al. (2013) with Carthamus caeruleus L collected from Tizi Ouzou and Setif regions respectively in Algeria; they found that the rhizomes of this plant are rich in tannins, anthocyanins, flavonoids, leucoanthocyanins, saponins, terpenoids and steroids, glycosides, mucilage, and coumarins. The results show that the total polyphenols compounds in rhizome aqueous crude extract of Carthamus caeruleus $L$ was low 13.08 $\pm 0.22 \mathrm{mg} \mathrm{GAE} / \mathrm{g} \mathrm{DM}$ as well as flavonoids with 5.02 $\pm 0.55 \mathrm{mg}$ EQ / g DW. Our results are in the same order with the findings of Baghiani et al. (2010) with the same genus collected from Setif northeast of Algeria; they found $10.358 \pm 0.428 \mathrm{mg}$ GAE/g DM of total polyphenols compounds and $1.508 \pm 0.094 \mathrm{mg} \mathrm{EQ} / \mathrm{g}$ DW of flavonoids in crude aqueous extract of roots of Carthamus caeruleus $L$. Our results are completely different from those obtained by Dahmani (2019) with methanolique extract of rhizomes of Carthamus caeruleus $L$ collected from Tizi Ouzou Northern Algeria ; they found a high total polyphenol content equal to $57,91 \pm 0.57$ mg EAG/g DM. These differences in the contents of total polyphenols, flavonoids and the absence or presence of phytochemicals in different regions can be explained by experimental conditions, climatic and environmental area, genetic heritage and period and time of harvest (Atmani, 2009; Allaoui et al., 2016; Tinuet al ., 2015).

Carrageenan is a polysaccharide induced paw edema in two phases. First phase: there are incidences such as releasing of histamine, serotonin and kinins while the second phase of edema is manifested by releasing of prostaglandins, protease and lysosome. The most clinically effective anti-inflammatory drugs are effective against the second phase (Posadas et al., 2004). In the present study, the treatment with aqueous extract of rhizome of Carthamus caeruleus $L$ shows a significant inhibitory activity in carrageenan induced paw inflammation in group A and B and it was important than Standard (Diclofenac) - The percentage inhibition of edema (\% INH) was dose dependent because the percentage increase in paw edema volume (\%AUG) was significantly decreased in mice treated with $300 \mathrm{mg} / \mathrm{kg}$ BW than with $150 \mathrm{mg} / \mathrm{kg} \mathrm{BW}$; these findings suggested that rhizome of Carthamus caeruleus $L$ has antagonist action against inflammation induced by carrageenan. The total inhibition of edema in group B was observed after six hours, which indicates a strong inhibitory activity of inflammation and all related appearances in tissues of epidermis and dermis. The inflammatory granuloma is a typical feature of subacute inflammatory reaction (Spector , 2004). Results in this study show a very important granuloma in histological slides of carrageenan control group, the treatment with Carthamus caeruleus $L$ has shown a minimal inflammatory granuloma. Our results are in the same order with Dahmani et al. (2018), Benhamou et al. (2013) and Benmansour et al. (2020) with Carthamus caeruleus $L$ collected from Tizi Ouzou, Setif and Tipaza, respectively. They have shown that the rhizomes of this herb were effective against inflammation induced by carrageenan in experimental animals. This anti-inflammatory activity could be due to the phytochemical compounds. The antiinflammatory activity of many phytoconstituents is manifested by their ability to inhibit the mediators of inflammation like iNOS, NO and cytokines like TNF- $\alpha$, IL-1 $\beta$, IL-6, IL-12, etc. The inhibition of chemokines as well as the inhibition of the activities of some enzymes responsible for inflammation like cycloxygenase-2 (COX2 ), prostaglandins and leukotrienes, reduction in reactive oxygen species (ROS), regulation of enzymatic antioxidants (superoxide dismutase, catalase, etc.) and non-enzymatic (glutathione, etc.) defense systems and the inhibition of neutrophil infiltration decrease expression of cell adhesion proteins (VCAM ,ICAM, PECAM). Metalloproteins were also tested as markers of anti-inflammatory activity. The down regulation of signaling pathways like NF- $\kappa \mathrm{B}$ by the active plants compounds were also tested by many studies (Lee et al., 2011; Hyam et al., 2013 ; Wu $\mathrm{X}$ et al., 2014 ).

Phytochemical screening of the rhizomes of Carthamus caeruleus $L$ in this study has revealed the richness of this plant in terms of phytoconstituents. The anti-inflammatory and anti-nociceptive effect of plants has been attributed to their secondary metabolites such as flavonoids, saponins, steroids, terpenoids, tannins and alkaloids (Birhane et al., 2020). The phytochemical studies on the rihzomes of 
Algerian Carthamus caeruleus $L \quad$ with gaz chromatography coupled to the mass spectroscopy were carried out by Dahmani et al. (2018) and Benhamou et al. (2013) who showed the presence of sesquiterpenes and fatty acids such as palmitic acid and mono(2-ethylhexyl) phthalate (MEHP) and 5-(hydroxymethyl)-2furancarboxaldehyde (5-HMF). Many pharmacological studies on active plant components showed that unsaturated fatty acids like palmitic acids are able to influence the biochemical properties of the membrane such as fluidity and permeability (Dhifi et al., 2013; Nasri et al., 2005 ). Xu et al (2007) and Oh et al (2012) indicated that (5-HMF) and (MEHP) had good biological activities, such as anti-inflammatory activity and antioxidant action.

\section{Conclusion}

Based on our findings from this study, it can be concluded that the aqueous extract of the rhizome of Carthamus caeruleus $L$ collected from Mostaganem northern of Algeria was effective against inflammation caused by carrageenan and decreased the volume of edema and pain in the paws of experimental animal. The phytochemical investigation showed that the rhizomes of this plant are rich in terms of secondary metabolites. The synergistic effect of these metabolites or one of these phytoconstituents could be responsible for the antiinflammatory activity. Hence, other researches should be made to isolate and identify the active compound responsible for this pharmacological activity.

\section{Acknowledgement}

This research was funded by the Algerian ministry of higher education and scientific research, PRFU project code "D01N01UN270120190001".

\section{Conflict of interest}

The authors declare no conflict of interest.

\section{References}

Allaoui M, Cheriti A, Chebouat E, Dadamoussa B and Gherraf N. 2016. Comparative study of the antioxidant activity and phenols and flavonoids contents of the ethyl acetate extracts from two Saharan chenopodacea: Haloxylon scoparium and Traganum nudatum . Algerian Journal of Arid And Environment (AJAE)., 6(1):71-79.

Alwashli A, Al-sobarry M, Alnamer R , Cherrah Y and Alaoui K. 2012. Analgesic and anti-inflammatory activities of Boswellia elongata balf methanolic extracts, as endemic plants in Yemen, Journal of Biologically Active Products from Nature ., 2( 2) : 9098.

Atmani D. 2009. Antioxidant capacity and phenol content of selected Algerian medicinal plants. Food Chemestry.,112 : 303-9.

Ayoola GA, Coker HA, Adesegun SA, Adepoju-Bello AA, Obaweya KE and Atangbayila TO. 2008. Phytochemical screening and antioxidant activities of some selected medicinal plants used for malaria therapy in Southwestern Nigeria. Tropical Journal of Pharmalogical Research., 7(3):1019-1024 .

Bagad S, Joseph J A , Bhaskaran N and Agarwal, A. 2013. "Comparative evaluation of anti-inflammatory activity of curcuminoids, turmerones, and aqueous extract of Curcuma longa . Advances in Pharmacological Sciences., 2013(805756) :1-7

Baghiani A, Boumerfeg S, Belkhiri F, Khennouf S, Charef S, Harzallah D, Arrar L and Mosaad A . 2010. Antioxidant and radical scavenging properties of Carthamus caeruleus L extracts grow wild in Algeria flora. Comunicata Scientiae., 1(2): 128-136.

Bancroft JD, Gamble M. 2008. Theory and practice of histological techniques, 6th Ed. Churchill Livingstone, pp .126127.

Benhamou A and Fazouane F. 2013. Ethnobotanical study, phytochemical characterization and healing effect of Carthamus coeruleus L. rhizomes. International Journal of Medicinal and Aromtic Plants., 3(1) : 61-68.

Benmansour N. 2020. Study of the Anti-Inflammatory and Healing Properties of the Rhizomes of Carthamus Caeruleus L. (Asteraceae) Harvested in the Region of Tipaza. Medical Technologies Journal.,4(1) : 525-6.

Bignotto L, Rocha J and Sepodes B .2009. Anti-inflammatory effect of lycopene on carrageenan-induced paw oedema and hepatic ischaemia-reperfusion in the rat. British Journal of Nutrition., 102(1) : 126-133.

Birhane SW and Asres K . 2014. Evaluation of analgesic and Anti-inflammatory activities of the root extracts of Indigofera spicata F in mice. Ethiopian Pharmcology J2 ., 14 :30-65.

Dahmani MM.2019. Evaluation de l'activité biologique des polyphénols de Carthamus caeruleus L (Asteraceae)., Universite de M’hamed Bouguera-Boumerdes ,Algérie.

Dahmani MM, Laoufi R, Selama O and Arab K. 2018. Gas chromatography coupled to mass spectrometry characterization, antiinflammatory effect, wound-healing potential, and hair growth-promoting activity of Algerian Carthamus caeruleus $L$ (Asteraceae). Indian Journal of Pharmacolgy .,50:123-9.

Dhifi W, Jelali N, Chaabani E, Beji M, Fatnassi S and Omri S. 2013 .Chemical composition of Lentisk (Pistacia lentiscus L.) seed oil. African Journal of Agricultural Research., 8(16) :13951400 .

Harborne JB. 1998. Phytochemical methods . A guide to modern techniques of plant analysis . 3rd ed. Chapman and Hall Int (Ed).NY, pp .49-188 .

Hyam SR, Lee IA, Gu W, Kim KA, Jeong JJ, Jang SE, Han MJ and Kim DH. 2013. Arctigenin ameliorates inflammation in-vitro and in-vivo by inhibiting the PI3K/AKT pathway and polarizing M1 macrophages to M2-like macrophages. European Journal of Pharmacology .,708: 21-9.

Lee CL, Huang CH, Wang HC, Chuang DW, Wu MJ, Wang SY, Hwang TL, Wu CC, Chen YL, Chang FR and Wu YC. 2011. First total synthesis of antrocamphin A and its analogs as antiinflammatory and anti-platelet aggregation agents. Organic and Biomolecular Chemistry ., 9: 70-3.

Missoun F, Bouabedelli F, Benhamimed E, Baghdad A and Djebli N. 2017. Phytochemical study and antibacterial activity of different extracts of Pistacia lentiscus $L$ collected from Dahra Region West of Algeria . Journal of Applied and Fundamental Sciences., 9(2): 669-648.

Mruthunjaya D , Hanumanthachar J , and Monnanda SN . 2016. Phytochemicals, Antioxidative and in vivo Hepatoprotective Potentials of Litsea floribunda (BL.) Gamble (Lauraceae) - An Endemic Tree Species of the Southern Western Ghats, India. Jordan Journal of Biological Sciences ., 9 (3). 163 - 171.

Nasri N, Khaldi A, Fady B and Triki S. 2005. Fatty acids from seeds of Pinus pinea L.Composition and population profiling. Phytochemistry., 66(14) :1729-1735. 
OECD/OCDE. 2000. OECD Guidelines for the testing of chemicals, revised draft guidelines, Acute Oral Toxicity Acute Toxic class methods, $423: 1-14$

Oguntibeju OO and Oluwafemi O. 2018. Medicinal plants with anti-inflammatory activities from selected countries and regions of Africa. Journal of Inflammation Research., 11 : 307-317.

Oh YC, Kang OH, Kim SB, Mun SH, Park CB and Kim YG . 2012. Anti-inflammatory effect of sinomenine by inhibition of pro-inflammatory mediators in PMA plus A23187-stimulated HMC-1 cells. European Review for Medicine and Pharmacology Sciences ,16:1184-91.

Payan DG, Katzung BG. 1995. Non-steroidal antiinflammatory drugs, Non-opoid Analgesics; Drugs used in Gout. Basic and Clinical Pharmacology. Prentice-Hall International, London, Edition 6th , pp . 536-59.

Posadas I and Inmaculada P .2004. Carrageenan-induced mouse paw edema is biphasic, age-weight dependent and displays differential nitric oxide cyclooxygenase-2 expression. British Journal of Pharmacology ., (142)2 : 331-8.

Roitt I, Brostoff, J and Male D . 2001. Cell migration and Inflammation, Immunology. Gower Medical Publications, New York, Edition 6th, pp .47-64.

Sarkar D. 2020 . The anti-inflammatory activity of plant derived ingredients: an analytical review. International Journal of Pharmacology Sciences \& Research .,11(2): 496-06.

Sofowara A. 1993. Medicinal plants and Traditional medicine in Africa Ibadan. Spectrum Books Ltd, Nigeria.

Spector WG. 1969. The Granulomatous Inflammatory Exudate. Internatinal Review and Experiemntal Pathololgy., 8 :51-5.
Sreedam CD , Subrata B , Sumon R , Sajal K, Saiful I and Sitesh CB.2012. Analgesic and Anti-inflammatory Activities of Ethanolic Root Extract of Swertia chirata (Gentianaceae) . Jordan Journal of Biological Science .,5( 1) : 31 - 36.

Tinu O and Kelly O. 2015. A Comparative Study of in vitro Antioxidant Activity and Phytochemical Constituents of Methanol Extract of Aframomum melegueta and Costus afer Leaves .Jordan Journal of Biological Sciences ., 8(4): 273 - 279.

Trease GE and Evans WC . 2009. Pharmacognsy 11 th ed. Brailliar Tiridel Can, Macmillian, urinary tract infections. Infection Disease Clin North America., 23: 355-385 .

Vasudevan A, Kalarickal V, Pradeep K, Ponnuraj K, Chittalakkottu S and Madathil KH.2012. Anti-Inflammatory Property of n-HexadecanoicAcid: Structural Evidence and Kinetic Assessment. Chemical Biology and Drug Design ., 80: 434-439.

Winter C. A. 1967 . Nonsteroid anti-inflammatory therapy II. Gaceta Medica de Mexico.,

97(5): 543-50.

Wu X, Yang Y, Dou Y, Ye J, Bian D, Wei Z, Tong B, Kong L, Xia Y and Dai Y.2014. Arctigenin but not arctiin acts as the major effective constituent of Arctium lappa L. fruit for attenuating colonic inflammatory response induced by dextran sulfate sodium in mice. International Immunopharmacology ., 23: 505-15.

Xu Q, Li YH and Lü XY. 2007.Investigation on influencing factors of 5-HMF content in schisandra. Journal of Zhejiang University-SCIENCE B., 8: 439-45. 